\title{
Bioassay for anti-chorionic gonadotrophin sera
}

\author{
Y. Yamamoto and Rosemarie B. Thau \\ The Population Council, Center for Biomedical Research, 1230 York Avenue, New York, \\ New York 10021, U.S.A.
}

\begin{abstract}
Summary. The method for a rapid bioassay for the neutralizing activities of antichorionic gonadotrophin sera is based on the inhibition of the increase in plasma testosterone concentrations in male mice after the injection of antiserum and human chorionic gonadotrophin (hCG). The antisera were obtained from rhesus monkeys immunized against the beta-subunit of ovine luteinizing hormone (oLH $\beta$ ). The antioLH $\beta$ sera neutralized the hCG-induced testosterone stimulation. A dose-response relationship for neutralization was found between 25 and $200 \mu \mathrm{l}$ antiserum. Anti-hCG sera raised in human, chimpanzee and rabbit also neutralized the biological activity of hCG. The major advantage of this method is that the single injection of antiserum given before hCG administration leads to the hormone-antibody reaction in vivo.
\end{abstract}

\section{Introduction}

Determination of the biological activity of antisera is essential for reproduction research using immunological methods. It is indispensable for the evaluation of the effectiveness of contraceptive vaccines in primates based on immunization against the $\beta$-subunit of hCG (hCG $\beta$ ) (Stevens, 1974; Hearn, 1976; Talwar et al., 1976), against C-terminal peptides of hCG $\beta$ (Stevens, Powell, Lee \& Griffin, 1981) and against the $\beta$-subunit of ovine luteinizing hormone (oLH $\beta$ ) (Thau \& Sundaram, 1980). The rapid and sensitive in-vitro methods for antibody determination cannot substitute for in-vivo assays for biological effectiveness.

Established bioassay procedures for the neutralizing activity of anti-LH and anti-hCG sera measure the inhibition of such gonadotrophic effects as the increase in weight of female (Snook \& Cole, 1965) or male (Robyn \& Diczfalusy, 1968) genital organs, the induction of ovulation (Sasamoto, 1969), and the depletion of ascorbic acid in the ovary (Rennels, 1964). The suppression of hCG-responsive ovarian alkaline phosphatase has also been reported (Ryle \& Sage, 1980). We describe here a rapid bioassay which is based on the inhibition of hCG-stimulated testosterone production in mice. This method is similar to that described by Ryle \& Sage (1980) but has the advantage that a single injection of antiserum is given before hCG administration so that hormone-antibody reactions occur in vivo, and thus the bioassay simulates more closely the biological interactions actually occurring in immunized animals.

\section{Materials and Methods}

Hormones. The hCG (10 000 i.u./vial, 3000 i.u./mg) was purchased from Sigma Chemical Co., St Louis, Missouri. The hCG for iodination (13000 i.u./mg) was a gift from Dr Y.-Y. Tsong; it was iodinated by the chloramine-T method according to Greenwood, Hunter \& Glover (1963). $\left[1,2,6,7,16,17-{ }^{3} \mathrm{H}(\mathrm{N})\right]$ Testosterone $(1 \cdot 0 \mathrm{mCi} / 0 \cdot 021 \mathrm{mg}$; sp. act. $137 \cdot 35 \mathrm{Ci} / \mathrm{mmol})$ was obtained 
from New England Nuclear, Boston, Massachusetts, and unlabelled testosterone from Sigma Chemical Co. The ovine LH $\beta$ (HSN-6-26B2) was a gift from Dr D. N. Ward. Human anti-hCG serum was obtained from a patient who had developed antibodies after gonadotrophin therapy. Rabbit anti-hCG $\beta$ serum was obtained from Dr C. C. Chang, and Dr W. Hobson provided the chimpanzee anti-hCG $\beta$ serum.

Antisera. Antisera were obtained from rhesus monkeys (Macaca mulatta) which had been immunized against oLH $\beta$ for 5-6 years to study several aspects of a contraceptive vaccine. The details of the immunization, antibody titre determination and antifertility effects, including the mechanisms of action, have been described previously (Sundaram et al., 1976; Thau, Sundaram, Thornton \& Seidman, 1979). Briefly, antibody titres were determined by the ability of the antiserum to bind $0.2 \mathrm{ng}$ iodinated hCG. The percentage binding of hCG by $2 \mu 1$ antiserum (c.p.m. precipitable with polyethylene glycol expressed as $\%$ of total c.p.m. added to the sample) was used as a relative measure of antibody titres of the monkey antiserum used for injection and of the mouse plasma collected at the end of the bioassay.

Bioassay. Male mice (NCS strain), obtained from The Rockefeller University, New York, were injected intraperitoneally with antiserum diluted in normal saline $(9 \mathrm{~g} \mathrm{NaCl} / 1)$ to a total volume of $300 \mu \mathrm{l}$. Control animals received $300 \mu \mathrm{l}$ saline. After 1,3 or $18 \mathrm{~h}$, hCG dissolved in $300 \mu \mathrm{l}$ of $1 \%$ of bovine serum albumin in saline was injected intravenously. Blood was collected by heart puncture under ether anaesthesia at various times after the hCG injection. The experiments were planned so that blood collections were routinely carried out between 16:00 and 17:00 h to minimize effects of circadian variations on plasma testosterone levels (Lucas \& Eleftheriou, 1980). Plasma was separated by centrifugation and stored at $4{ }^{\circ} \mathrm{C}$ until analysis, usually not longer than 1 week although storage for up to 6 months does not change the results.

Plasma testosterone concentrations were determined by radioimmunoassay (Janne, Apter \& Vihko, 1974). The antiserum was obtained from Dr O. Janne. The cross-reactivity with dihydrotestosterone was $10 \%$. The limit of sensitivity was $3.5 \mathrm{pg}$. Intra- and interassay coefficients of variation were 8.5 and $13.1 \%$, respectively.

Statistics. Student's $t$ test was used to compare the means of various groups; a Hewlett-Packard program for curve fitting (linear regression analysis) was used to determine the correlation of the amount of antibody injected with plasma testosterone concentrations.

\section{Results}

Age-effect on testosterone response. Plasma testosterone concentrations were determined in 3-week (body weight: $10-12 \mathrm{~g}), 7$-week $(25-30 \mathrm{~g})$ and 10-week $(35-40 \mathrm{~g})$ old mice with and without hCG injections. The 3-week-old mice had undetectable basal testosterone levels and showed no increase after hCG treatment. In 7- and 10-week-old mice, the mean \pm s.e.m. basal levels $(0.25 \pm 0.04 \mathrm{ng} / \mathrm{ml}, \mathrm{N}=7$, and $0.25 \pm 0.14 \mathrm{ng} / \mathrm{ml}, \mathrm{N}=4$, respectively) and increases induced $2 \mathrm{~h}$ after the administration of 2.0 i.u. hCG $(30.4 \pm 0.9 \mathrm{ng} / \mathrm{ml}, \mathrm{N}=7$, and $32.4 \pm 4.6 \mathrm{ng} / \mathrm{ml}, \mathrm{N}=6$, respectively) were similar, but the older group showed more variation in response to $\mathrm{hCG}$. We therefore routinely used 7-week-old mice in the bioassay. Contrary to the findings reported for 2 other strains of mice (Bartke \& Dalterio, 1975), we found no evidence for episodic secretion of testosterone in 3-, 7- and 10-week old mice of the NCS strain.

Effects of amounts and time of hCG administration. As shown in Text-fig. 1, maximum response of plasma testosterone levels $2 \mathrm{~h}$ after hCG was reached with 2.0 i.u. hCG. A dose of 0.25 i.u. hCG induced testosterone levels significantly higher $(P<0.005)$ than those of mice injected with saline $(0.3 \pm 1 \mathrm{ng} / \mathrm{ml}, \mathrm{N}=7)$. Half-maximal response was achieved by approximately $0.8 \mathrm{i} . \mathrm{u}$. hCG and this was therefore used as the standard dose for testing the neutralizing activity of anti-CG or antioLH $\beta$ antisera. Using 2.0 i.u. hCG, testosterone levels were measured $1,2,4$ and $6 \mathrm{~h}$ after hCG injection: maximum response of testosterone to $\mathrm{hCG}$ occurred within $1 \mathrm{~h}(33.7 \pm 6.6 \mathrm{ng} / \mathrm{ml}$, 
$\mathrm{N}=4)$ and no further change was seen at $2(32.3 \pm 0.3 \mathrm{ng} / \mathrm{ml}, \mathrm{N}=4)$ or $4 \mathrm{~h}(35.3 \pm 1.5 \mathrm{ng} / \mathrm{ml}$, $\mathrm{N}=4)$. By $6 \mathrm{~h}$, testosterone levels had declined significantly $(24.1 \pm 2.9 \mathrm{ng} / \mathrm{ml}, \mathrm{N}=4 ; P<0.05)$. For our routine assays, we therefore decided to collect blood samples $2 \mathrm{~h}$ after the hCG injection.

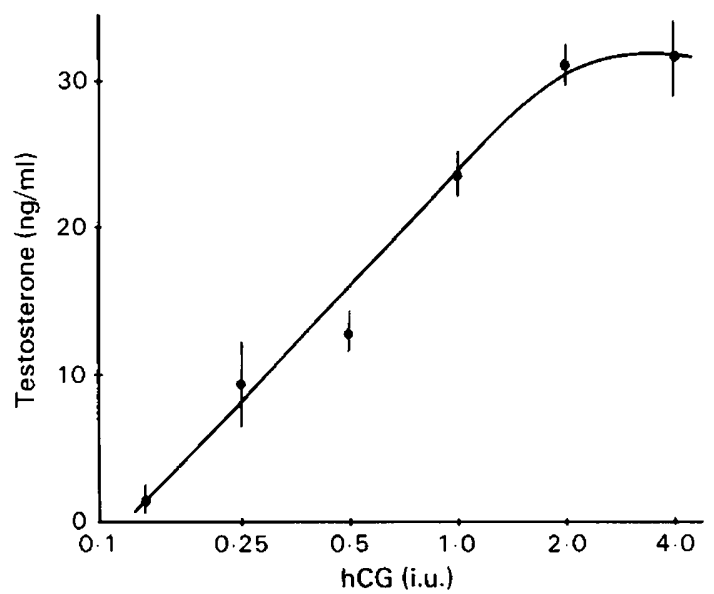

Text-fig. 1. Dose-response of plasma testosterone (mean \pm s.e.m., $\mathrm{N}=4$ or 5 ) $2 \mathrm{~h}$ after the intravenous injection of increasing amounts of hCG. A linear log dose-response was found between 0.25 and 2 i.u. of hCG $(\mathrm{N}=28, r=0.848, P<0.001)$.

Antibody levels in mouse plasma following the intraperitoneal injection of oLHB-antiserum. The purpose of this study was to determine whether the antibody titre obtained in mice corresponded to that which was expected from the amount of antiserum injected. The ability of mouse plasma to bind iodinated hCG was measured in samples collected $3 \mathrm{~h}$ after administration of various volumes (adjusted to $300 \mu \mathrm{l}$ with saline) of a high-titre anti-oLH $\beta$ serum (M616). Percentage binding of iodinated hCG by $20 \mu \mathrm{l}$ mouse serum at a final dilution of $1: 40$ (titre) is shown in Table 1 . The antibody titres in the mouse plasma correlated well $(\mathrm{N}=23, r=0.937, P<0.001)$ with the doses of oLH $\beta$ antiserum injected. Maximum plasma concentrations of antibodies (titre $50 \%$ ) were reached after injection of $\geqslant 70 \mu \mathrm{loLH} \beta$ antiserum. This titre is to be expected if complete absorbance of the injected antiserum is assumed and the dilution of the antiserum by the mouse plasma is taken into account.

Table 1. Antibody titres (mean \pm s.e.m. for no. of tests indicated) in mouse plasma $3 \mathrm{~h}$ after injections of different volumes of a high-titre oLH $\beta$ antiserum $(71 \%, \mathrm{M} 616)$

\begin{tabular}{ccc}
\hline $\begin{array}{c}\text { Antiserum vol.* } \\
(\mu \mathrm{l})\end{array}$ & $n$ & $\begin{array}{c}\text { Antibody titre } \\
(\mathrm{B} / \mathrm{T} \times 100) \dagger\end{array}$ \\
\hline 10 & 5 & $23.7 \pm 1.8$ \\
30 & 4 & $35.8 \pm 2.5$ \\
70 & 5 & $49.1 \pm 0.5$ \\
100 & 4 & $50.3 \pm 1.3$ \\
200 & 4 & $54.2 \pm 0.3$ \\
\hline
\end{tabular}
saline.

* Total volume was adjusted to $300 \mu$ with

$\dagger$ Non-specific binding was $5.6 \% . \mathrm{T}=$ total counts added to test tube, $\mathrm{B}=$ counts bound after incubation. 
Effects of time intervals between antiserum and hCG injection. As shown in Table 2, antibody titres in mouse plasma were lower and more variable at $1 \mathrm{~h}$ than at 3 or $18 \mathrm{~h}$, indicating that $1 \mathrm{~h}$ was not sufficient for optimum absorption of the antibodies from the peritoneal cavity although testosterone production was already significantly reduced. In our routine assay, we therefore injected hCG $3 \mathrm{~h}$ after administration of the antiserum.

Table 2. Effects of time intervals between the intraperitoneal injections of $100 \mu$ l of a medium-titre $(46 \%$, M612) antiserum (diluted to $300 \mu \mathrm{l}$ with saline) and the intravenous injection of 2.0 i.u hCG on antibody titres and plasma testosterone in mice

\begin{tabular}{cccc}
\hline $\begin{array}{c}\text { Time } \\
(\mathrm{h})\end{array}$ & $n$ & $\begin{array}{c}\text { Antibody titres* } \\
(\%)\end{array}$ & $\begin{array}{c}\text { Testosterone conc. } \\
(\mathrm{ng} / \mathrm{ml})\end{array}$ \\
\hline Control $\dagger$ & 5 & 0 & $32 \cdot 1 \pm 3 \cdot 8^{\mathrm{a}}$ \\
1 & 6 & $22 \cdot 0 \pm 5 \cdot 1$ & $18 \cdot 3 \pm 3 \cdot 3^{\mathrm{b}}$ \\
3 & 6 & $29 \cdot 8 \pm 2 \cdot 2$ & $14 \cdot 2 \pm 2 \cdot 1^{\mathrm{c}}$ \\
18 & 5 & $31 \cdot 2 \pm 0 \cdot 9$ & $16 \cdot 2 \pm 2 \cdot 0^{\mathrm{d}}$ \\
\hline
\end{tabular}

Values are mean \pm s.e.m.

* Measured at $1: 40$ dilution of mouse plasma. The plasma samples were collected 3,5 and and $20 \mathrm{~h}$ after antiserum administration, $2 \mathrm{~h}$ following the injection of $\mathrm{hCG}$.

† hCG injection only.

$\mathrm{a} / \mathrm{b}: P<0.025 ; \mathrm{a} / \mathrm{c}: P<0.005 ; \mathrm{a} / \mathrm{d}: P<0.01$ (Student's $t$ test).

Established assay method and its application. The conditions chosen for the routine bioassay were as follows: (a) antiserum (diluted to a total volume of $300 \mu \mathrm{l}$ with saline) was injected i.p. into 7 week-old $(25-30 \mathrm{~g})$ mice; (b) $3 \mathrm{~h}$ later a s.c. injection of hCG $(0.8 \mathrm{i} . \mathrm{u}$. diluted in $300 \mu \mathrm{l} 1 \% \mathrm{BSA}$ in saline) was given; (c) $2 \mathrm{~h}$ later, blood was collected under ether anaesthesia; and (d) testosterone concentrations were measured in plasma samples by radioimmunoassay.

The above method was used to measure the ability of a rhesus anti-oLH $\beta$ serum (M616) with a high antibody titre $(71 \%$ binding of iodinated hCG in vitro, at a final dilution of $1: 400)$ to neutralize the biological activity of hCG. More than $12.5 \mu \mathrm{l}$ of oLH $\beta$ antiserum were needed to inhibit hCG action on testosterone production (Table 3). The effect was dose-dependent between 25 and $200 \mu \mathrm{l}$ antiserum $(\mathrm{N}=28, r=0.750, P<0.001)$. However, low doses of antiserum $(6.25$ and $12.5 \mu \mathrm{l})$ potentiated the action of $\mathrm{hCG}$. The increase in plasma testosterone levels was dose-related between 3.1 and $12.5 \mu$ antiserum $(\mathrm{N}=19, r=0.486, P<0.03)$. The assay was also tested for several other anti-chorionic gonadotrophin sera and testosterone production was inhibited in a dose-related manner (Table 4).

Table 3. Effect of anti oLH $\beta$ serum (M616, high antibody titre) on plasma testosterone after injection of $0.8 \mathrm{i}$.u. hCG in mice

\begin{tabular}{|c|c|c|c|}
\hline $\begin{array}{c}\text { Volume of anti-oLH } \beta \\
\text { serum }(\mu \mathrm{l})^{*}\end{array}$ & $\begin{array}{l}\text { No. of } \\
\text { mice }\end{array}$ & $\begin{array}{l}\text { Testosterone conc. } \\
(\mathrm{ng} / \mathrm{ml})\end{array}$ & $\begin{array}{l}\% \text { of control } \\
\text { testosterone conc. }\end{array}$ \\
\hline 0 (control) & 5 & $10.9 \pm 2.5$ & 100 \\
\hline 3.13 & 5 & $11.9 \pm 2.3$ & $109 \cdot 5 \pm 21 \cdot 3$ \\
\hline $6 \cdot 25$ & 4 & $13.8 \pm 3.0$ & $127.1 \pm 13.9$ \\
\hline $12 \cdot 5$ & 5 & $18 \cdot 1 \pm 3.4$ & $166.4 \pm 30.8$ \\
\hline $25 \cdot 0$ & 5 & $8.0 \pm 1.7$ & $73.2 \pm 15.8$ \\
\hline $50 \cdot 0$ & 4 & $7.5 \pm 1.5$ & $68.7 \pm 13.7$ \\
\hline $75 \cdot 0$ & 5 & $6 \cdot 1 \pm 1.2$ & $55.7 \pm 11.0$ \\
\hline $100 \cdot 0$ & 5 & $2.4 \pm 0.9$ & $21.7 \pm 7.8$ \\
\hline $200 \cdot 0$ & 4 & $1.7 \pm 1.3$ & $15.9 \pm 13.2$ \\
\hline
\end{tabular}

Values are mean \pm s.e.m.

* Total volume adjusted to $300 \mu$ l with saline. Control received normal saline only. 
Table 4. Neutralizing activity of antigonadotrophin sera raised in different animals

\begin{tabular}{|c|c|c|c|c|}
\hline Species & Antibody type & $\begin{array}{c}\text { Antiserum vol. } \\
(\mu \mathrm{l})\end{array}$ & $\begin{array}{l}\text { Testosterone conc. } \\
\text { (ng/ml) }\end{array}$ & $\begin{array}{l}\% \text { of control } \\
\text { testosterone conc. }\end{array}$ \\
\hline Human & Anti-hCG & $\begin{array}{c}\text { Control } \\
20 \\
100 \\
200 \\
300\end{array}$ & $\begin{array}{r}25.1 \pm 1.5 \\
17.7 \pm 3.0 \\
19.8 \pm 3.5 \\
5.8 \pm 2.1 \\
1.4 \pm 0.7\end{array}$ & $\begin{array}{l}100 \\
70 \cdot 5 \pm 11 \cdot 8 \\
78 \cdot 9 \pm 15 \cdot 0 \\
23 \cdot 1 \pm 8 \cdot 3 \\
5 \cdot 6 \pm 3 \cdot 0\end{array}$ \\
\hline Chimpanzee & Anti-hCG $\beta$ & $\begin{array}{c}\text { Control } \\
20 \\
100\end{array}$ & $\begin{array}{r}13.0 \pm 2.2 \\
7.2 \pm 1.6 \\
1.5 \pm 0.2\end{array}$ & $\begin{array}{l}100 \\
55 \cdot 4 \pm 12 \cdot 3 \\
11.5 \pm 1.8\end{array}$ \\
\hline Rabbit & Anti-hCG $\beta$ & $\begin{array}{c}\text { Control } \\
20 \\
100\end{array}$ & $\begin{array}{r}19 \cdot 3 \pm 1 \cdot 7 \\
3.0 \pm 2.0 \\
0.5 \pm 0.3\end{array}$ & $\begin{array}{r}100 \\
15.5 \pm 10 \cdot 6 \\
2.6 \pm 1.8\end{array}$ \\
\hline
\end{tabular}

Values are mean \pm s.e.m.

\section{Discussion}

We have developed a simple, rapid method to test the in-vivo neutralizing activity of anti-chorionic gonadotrophin sera. The method is based on inhibiton of testicular steroidogenesis in response to a chorionic gonadotrophic stimulus in mice. In some bioassays for anti-gonadotrophic sera, preincubated mixtures of hormone and antiserum are injected into the animals (Snook \& Cole, 1965; Robyn \& Diczfalusy, 1968). Hormone--antibody binding reactions, therefore, occur in vitro. To simulate more closely the interactions taking place in actively or passively immunized animals, we injected the antisera $3 \mathrm{~h}$ before hCG administration. This interval between antiserum and hCG injection was sufficient for the absorption of antibodies from the peritoneum, as confirmed by measurements of antibody titres in mouse plasma.

The paradoxical augmentative effect (Table 3) of small amounts of antigonadotrophic sera has been reported previously by Snook \& Cole (1965) and was termed 'progonadotrophic effect' in their bioassay system based on inhibition of the rat uterine response to hCG. The mechanism of this effect is unclear. Butler (1975) suggested that the antibody-antigen complex may act directly and possibly more effectively than free hormone on the receptor system of the target cell. Hormonereceptor interaction may also be enhanced by a decrease in the metabolic clearance rate of antibody-bound hormones. We have observed reduced clearance of hCG in 6 out of 7 rhesus monkeys immunized against oLH $\beta$ (unpublished observations).

As can be seen in Text-fig. 1 and Table 3, we encountered considerable individual variation in hCG-induced testosterone concentrations as well as in neutralizing activity of antisera, especially when small amounts of antiserum were used. These variations are a result of the summation of many in-vivo reactions such as absorption (of the antiserum), metabolism, excretion, and functional actions of all the components involved (antibody, hCG, testosterone) in addition to the immunological reaction.

The dose-response for neutralization of gonadotrophic stimulation ranged from 25 to $200 \mu l$ antiserum in our typical high-titre serum (Table 3). Similar steep changes in response within a narrow range of antiserum were also reported for other bioassays (Snook \& Cole, 1965; Ryle \& Sage, 1980). For testing unknown antisera, the largest amount of antiserum possible (200 or $300 \mu 1)$ should be injected to increase the likelihood of a significant reduction in testosterone response. Simultaneously, a smaller amount $(20$ or $30 \mu \mathrm{l})$ should be injected, so that a dose-response, if present, can be observed.

In spite of the limitations inherent in bioassay methods and the lack of absolute standards, determination of the in-vivo neutralizing capacity of antigonadotrophic sera is essential for charac- 
terization of antisera. The bioassay we have reported here is a simple and rapid method to test neutralizing activity of antigonadotrophic sera in mice. The neutralizing activity of rhesus antioLH $\beta$ antisera in mice correlated well with antibody titres.

This work was undertaken as part of the contraceptive development program sponsored and coordinated by the International Committe for Contraception Research of the Population Council, Inc., New York. The financial support provided by the U.S. Agency for International Development (Grant AID/phA 1116), the Ford Foundation, the Rockefeller Foundation and the George J. Hecht Fund is gratefully acknowledged. The content does not necessarily reflect the policy of any of the funding sources. We thank Mr R. Otero, Mr A. Rovitzky and Ms L. S. Seidman for skilful technical assistance; Ms L. McKeiver and Mrs E. Jenkins for typing the paper; and Dr C. W. Bardin for critical review.

\section{References}

Bartke, A. \& Dalterio, S. (1975) Evidence for episodic secretion of testosterone in laboratory mice. Steroids 26, 749-756.

Butler, J.E. (1975) The immune response to protein and protein-conjugated antigens and the possible consequences of resultant in vivo reactions. In Immunization with Hormones in Reproduction Research, pp. 11-30 Ed. E. Nieschlag. North-Holland/American Elsevier, New York.

Greenwood, F.C., Hunter, W.M. \& Glover, J.S. (1963) The preparation of ${ }^{131}$ I-labelled human growth hormone of high specific radioactivity. Biochem. J. 89, 114-123.

Hearn, J.P. (1976) Immunization against pregnancy. Proc. R. Soc. Lond. B 195, 149-160.

Janne, O., Apter, D. \& Vihko, R. (1974) Assay of testosterone, progesterone and $17 \alpha$-hydroxyprogesterone in human plasma by radioimmunoassay after separation on hydroxyalkyloxypropyl sephadex. $J$. Steroid Biochem. 5, 155-162.

Lucas, L.A. \& Eleftheriou, B.E. (1980) Circadian variations in concentrations of testosterone in the plasma of male mice: a difference between BALB/cBy and C57BL/6By inbred strains. J. Endocr. 87, 37-46.

Rennels, E.G. (1964) Titration of antibodies to luteinizing hormone by means of ovarian ascorbic acid depletion test. Endocrinology 74, 290-293.

Robyn, C. \& Diczfalusy, E. (1968) Bioassay of antigonadotrophic sera. 2. Assay of the human chorionic gonadotrophin (hCG) and luteinizing hormone (LH) neutralizing potencies. Acta endocr., Copenh. 59, 261276.

Ryle, M. \& Sage, J. (1980) A procedure for testing potential inhibitors of human chorionic gonadotrophin activity in vivo. J. Reprod. Fert. 60, 243-245.
Sasamoto, S. (1969) Inhibition of HCG-induced ovulation by anti-HCG serum in immature mice pretreated with PMSG. J. Reprod. Fert. 20, 271-277.

Snook, R.B. \& Cole, H.H. (1965) Bio-assay of antisera against human chorionic gonadotropin. Endocrinology 76, 20-26.

Stevens, V.C. (1974) Fertility control through active immunization using placenta proteins. Acta endocr. Copenh., Suppl. 194, 357-369.

Stevens, V.C., Powell, J.E., Lee, A.C. \& Griffin, D. (1981) Antifertility effects of immunization of female baboons with C-terminal peptides of the $\beta$-subunit of human chorionic gonadotropin. Fert. Steril. 36, 98-105.

Sundaram, K., Chang, C.C., Laurence, A., Brinson, A.O., Atkinson, L.E., Segal, S.J. \& Ward, D.N. (1976) The effectiveness in rhesus monkeys of an antifertility vaccine based on neutralization of chorionic gonadotropin. Contraception 14, 639-653.

Talwar, G.P., Sharma, N.C., Dubey, S.K., Salahuddin, M., Das, C., Ramakrishnam, S., Kumar, S. \& Hingorani, V. (1976) Isoimmunization against human chorionic gonadotropin with conjugates of processed $\beta$ subunit of the hormone and tetanus toxoid. Proc. natn. Acad. Sci. U.S.A. 73, 218-222.

Thau, R.B. \& Sundaram, K. (1980) The mechanism of action of an antifertility vaccine in the rhesus monkey: reversal of the effects of antisera to the $\beta$-subunit of ovine luteinizing hormone by medroxyprogesterone acetate. Fert. Steril. 33, 317-320.

Thau, R.B., Sundaram, K., Thornton, Y.S. \& Seidman, L.S. (1979) Effects of immunization with the $\beta$-subunit of ovine luteinizing hormone on corpus luteum function in the rhesus monkey. Fert. Steril. 31, 200204.

Received 17 August 1982 